\title{
A MEDIAÇÃO E A SOLUÇÃO DOS CONFLITOS NO ESTADO DEMOCRÁTICO DE DIREITO. O "JUIZ HERMES" E A NOVA DIMENSÃO DA FUNÇÃO JURISDICIONAL / MEDIATION AND CONFLICT SOLUTION IN THE DEMOCRATIC LAW STATE. THE "HERMES JUDGE" AND THE NEW DIMENSION OF JUDICIAL FUNCTION
}

\author{
Humberto Dalla Bernardina de Pinho ${ }^{1}$ \\ Karol Araújo Durço ${ }^{2}$
}

\section{Resumo}

O texto procura fazer uma análise do impacto da mediação no ordenamento processual brasileiro. Para tanto, partindo de uma contextualização jurídico-filosófica da jurisdição e do Estado, faz uma abordagem crítica da iniciativa legislativa e propõe uma visão interdisciplinar sobre a mediação.

Sugere-se o deslocamento da ênfase da solução do conflito do Poder Judiciário para as próprias pessoas envolvidas no litígio, tendo como marcos teóricos a cultura da pacificação, a democracia constitucional-deliberativa e as modernas regras da intervenção mínima do Estado e da máxima cooperação entre as partes.

Palavras-chave: Mediação. Mecanismos alternativos de resolução de disputas. Democracia.

\begin{abstract}
This paper seeks to analyze the impact of mediation in the Brazilian procedural law. To do so, from a legalphilosophical context of the jurisdiction and the state, is a critical approach to legislative initiative and proposes an interdisciplinary view about mediation.

It is suggested that the shift of emphasis from the solution of the conflict of the Judiciary for the people involved in the dispute, having as theoretical frames the culture of peace, constitutional, deliberative democracy and the modern rules of minimal state intervention and maximum cooperation between parties.
\end{abstract}

Keywords: Mediation. Alternative dispute resolution mechanisms. Democracy.

\footnotetext{
${ }^{1}$ Pós-Doutor em Direito (Uconn Law School). Mestre, Doutor e Professor Adjunto de Direito Processual Civil na UERJ. Professor dos Cursos de Graduação, Mestrado e Doutorado da UNESA. Promotor de Justiça Titular no Estado do Rio de Janeiro. 2

Mestre em Direito Processual pela Universidade Federal do Espírito Santo UFES. Professor da Universidade Presidente Antônio Carlos UNIPAC. Advogado
} 
"a conciliação desmancha a lide, a decompõe nos seus conteúdos conflituosos, avizinhando os conflitantes que, portanto, perdem a sua identidade construída antagonicamente ${ }^{2} . "$

Considerando o objetivo primordial do presente ensaio no sentido de tratar da mediação e das perspectivas para o processo civil contemporâneo, no ano em que o Projeto ${ }^{3}$ de Lei 4.827 completa dez anos de tramitação no Congresso Nacional, faz-se necessário, previamente, contextualizar o instituto sob uma perspectiva pós-positivista, de um direito como sistema aberto e, ainda, no interior de uma moldura constitucional-democrático-deliberativa de direito e de processo.

Pois bem, para garantirmos tal intento, antes de uma análise específica e dogmática da mediação, é preciso discorrer, ainda que brevemente, sobre a jurisdição em uma perspectiva evolutiva, apontando-se, igualmente, para os objetivos e para um estágio ideal de sua prestação atinente ao modelo de Estado e de sociedade que almejamos construir.

Sendo assim, para facilitar a compreensão das idéias fundamentais que buscaremos a seguir e como premissas jurídico-filosóficas para um entendimento sobre o porquê da necessidade de se buscar outros métodos de solução de conflitos, partiremos de uma singela análise de três modelos fictícios de juiz e de jurisdição, os quais, como veremos, coadunam-se aos três grandes estágios dos Estados ocidentais modernos e pós-modernos.

Nesse quadro, para cumprirmos esta meta introdutória, possibilitando a visibilidade do enquadramento e do papel da mediação em um contexto jurídico-social mais amplo e interdisciplinar, valemo-nos dos estudos do belga François $\mathrm{Ost}^{4}$ o qual, em artigo intitulado “Júpter, Hércules, Hermes: Tres modelos de Juez” identificou e caracterizou os modelos de juiz a partir dos quais desenvolveremos as considerações propedêuticas que se seguem.

Portanto, partindo dos estudos do referido autor, almejamos realizar uma associação entre cada um dos mencionados personagens e os modelos de Estado de Direito que inspiraram as Constituições dos Estados ocidentais do século XVIII até o século XX, quais sejam, os modelos

\footnotetext{
${ }^{2}$ RESTA, Eligio (trad. Sandra Vial). O Direito Fraterno. Santa Cruz do Sul: EDUNISC, 2004. Obj. de citação p. 119.

${ }^{3}$ A íntegra do Projeto em sua versão mais atual, em como as versões anteriores podem ser conferidas em nosso sítio, em http://www.humbertodalla.pro.br, ou no sítio do Instituto Brasileiro de Direito Processual - IBDP, em http://www.direitoprocessual.org.br, acesso em 20 de abril de 2008.

${ }^{4}$ OST, François. Júpter, Hércules, Hermes: Tres modelos de Juez. In: DOXA, no 14, 1993. pp. 169-194. < http://www.cervantesvirtual.com/servlet/SirveObras/01360629872570728587891/index.htm>. Acesso em 14 de novembro de 2006.
} 


\section{Quaestio Iuris}

liberal, social e democrático, para, ao final, sob a égide da construção e do estabelecimento desse último, localizarmos e estudarmos a mediação como método mais amplo, democrático e pluralista de se pacificarem muitos dos conflitos presentes em nossa sociedade.

Assim, uma vez realizada a análise dos ensinos de Ost sob a perspectiva dos paradigmas decorrentes de cada um dos modelos de organização estatal citados, buscaremos identificar as vantagens de um juiz do Estado Democrático para os fins almejados pela processualística contemporânea, notadamente sob a perspectiva de um processo participativo e cooperativo e sob a moldura da teoria do discurso e de uma racionalidade comunicativa; apontaremos, também, para a mediação como instância indispensável ao cumprimento de tão elevados escopos jurídicosociais e como instituto complementar à jurisdição tradicional.

Destaque-se, primeiramente, então, que a associação entre os modelos de juiz e os modelos de Estado sob a égide dos quais aqueles exercem suas funções jurisdicionais não é destituída de sentido e importância. Com a referida associação, portanto, o que se quer fazer compreender é a existência de uma relação interna entre os fundamentos de um Estado e o modo pelo qual é prestada a jurisdição e são pacificados os conflitos no mesmo.

Nessa esteira, a intenção é demonstrar que os mecanismos de atuação das partes envolvidas na relação processual, assim como suas prerrogativas, direitos e deveres, decorrem do sistema institucional do Estado no qual se inserem, bem como os próprios meios de pacificação de conflito.

Por outras palavras, a atividade jurisdicional e a presença dos denominados equivalentes jurisdicionais ${ }^{5}$ (autotutela, autocomposição, mediação e julgamento de conflitos por tribunais administrativos) nada mais é do que um reflexo do modelo de Estado sob o qual esta é exercida.

Em sociedades primitivas a pacificação dos conflitos era feita pela força privada; em Estados despóticos a pacificação dos conflitos confundia-se com o próprio Rei; em Estados liberais a mesma era ditada pela lei do mercado; em Estados sociais a pacificação dos conflitos correspondia ao paternalismo prestacionista; e em Estados democráticos a pacificação dos conflitos deve ser legitimada por um discurso processual intersubjetivo além de reclamar, portanto, métodos outros que a estrita e fria atuação estatal por meio da atividade jurisdicional.

\footnotetext{
${ }^{5}$ DIDIER JÚNIOR, Fredie. Curso de Direito Processual Civil: Teoria Geral do Processo e Processo de Conhecimento. Vol. 1. $9^{\mathrm{a}}$ ed. rev. ampl. atu. Salvador: Juspodivm, 2008. Obj. de ref. p. 74.
} 
Nesse quadro, fazendo um corte a partir do período moderno e pós-absolutista, o primeiro modelo de juiz a ser tratado corresponde, na lição de Ost, ao juiz Júpiter, o qual se vincula ao paradigma do Estado Liberal.

Assim, apenas para recordar, vale dizer que Estado Liberal ${ }^{6}$ clássico, frente a sua finalidade principal de garantir a liberdade dos cidadãos, foi assinalado por um rígido sistema de limitação de seus poderes a fim de se criar uma esfera de proteção jurídica privada ${ }^{8}$.

Nesse Estado a lei não levava em consideração diferenças na condição social dos indivíduos, pois sua intenção era dar tratamento igual às pessoas somente em sentido formal, devendo ser, portanto, concomitantemente "clarividente e cega" ${ }^{7}$. Este modelo é fruto do pensamento positivista ${ }^{8}$, de um direito codificado cujo pilar central é a "norma fundamental". Nas palavras de $\mathrm{Ost}^{11}$, a codificação representaria coerência, completude, clareza, não redundância, simplicidade e manejabilidade pondo as coisas simples claras e comunicáveis.

Outra nota caracterizadora do Estado Liberal é que o mesmo representa a passagem de um modelo transcendental de direito de bases metafísicas para um direito racional de base lógicodedutiva. Sendo, pois, um sistema legislado fechado e autônomo ${ }^{9}$ distinguindo-se pelo monismo jurídico (possui uma base soberana: a lei); monismo político (o poder é centralizado nas mãos de um soberano); racionalidade dedutiva (já que de formato piramidal a partir da norma

\footnotetext{
${ }^{6}$ Luiz Guilherme Marinoni destaca que: "O Estado Liberal de Direito, diante da necessidade de condicionar a força do Estado à liberdade da sociedade, erigiu o princípio da legalidade como fundamento para a sua imposição. Esse princípio elevou a lei a um ato supremo com a finalidade de eliminar as tradições jurídicas do Absolutismo e do Ancien Régime. A Adminsitração e os juízes, em face desse princípio, ficaram impedidos de invocar qualquer direito ou razão pública que se chocasse com a lei. [...] Tal princípio, assim, constituiu um critério de identificação do direito; o direito estaria apenas na norma jurídica, cuja validade não dependeria de sua correspondência com a jutiça, mas somente de ter sido produzida por uma autoridade dotada de competência normativa". MARINONI, Luiz Guilherme. A Jurisdição no Estado Contemporâneo. In: (Coord.). Estudos de Direito Processual Civil: homenagem ao Professor Egas Dirceu Moniz de Aragão. São Paulo: Revista dos Tribunais, 2005, pp. 13-66. Obj. de citação p. 14. 8 Ver TARELLO, Giovanni. Storia della cultura giuridica moderna. Bologna: Il Mulino, 1976. Obj. de ref. p. 278 e seguintes.

${ }_{7}^{7}$ MONTESQUIEU. Do espírito das leis. São Paulo: Abril Cultural, 1973. Obj. de citação p. 160.

8 "O positivismo jurídico [...] partindo da idéia de que o direito se resume à lei e, assim, é fruto exclusivo das casas legislativas, limita a atividade do jurista à descrição da lei e a busca da vontade do legislador. O positivismo jurídico nada mais é do que uma tentativa de adaptação do positivismo filosófico ao domínio do direito. Imaginouse, sob o rótulo de positivismo jurídico, que seria possível criar uma ciência jurídica a partir dos métodos das ciências naturais, basicamente a objetividade da observação e a experimentação. [...] O positivismo não se preocupava com o conteúdo da norma, uma vez que a validade da lei estava apenas na dependência da observância do procedimento estabelecido para a sua criação. Além do mais, tal forma de pensar o direito não via lacuna no ordenamento jurídico, afirmando a sua plenitude. A lei, compreendida como corpo de lei ou como Código, era otada de plenitude e, portanto, sempre teria que dar resposta aos conflitos de interesses". MARINONI, Luiz Guilherme. A Jurisdição no Estado Contemporâneo. In: _ (Coord.). Estudos de Direito Processual Civil: homenagem ao Professor Egas Dirceu Moniz de Aragão. São Paulo: Revista dos Tribunais, 2005, pp. 13-66. Obj. de citação p. 17. 11 OST, François. Júpter, Hércules, Hermes: Tres modelos de Juez. Obj. de ref. p. 174-175.

${ }_{9}^{9}$ HABERMAS, Jürgen. Direito e Democracia: entre facticidade e validade. Vol. I. Tradução: Flávio Beno

Siebeneichler. Rio de Janeiro: Tempo Brasileiro, 1997. Obj. de ref. p. 250.
} 
fundamental); e futuro controlado (crença legislativa de uma evolução histórica). Nesse modelo o direito se resumiria a "lei" vista em um sistema piramidal. Desta pirâmide irradiaria toda a justiça $^{10}$.

Por óbvio, esta formatação de Estado teve repercussão sobre a atividade jurisdicional e os métodos de pacificação de conflito, porque de nada adiantaria conformar a atividade legislativa e permitir que o juiz ou as partes envolvidas no conflito interpretassem livremente a lei em face da realidade social.

Afirmava Montesquieu ${ }^{11}$, sobre este sistema, que o julgamento deveria ser apenas um “texto exato da lei”, pois de outra maneira constituiria "uma opinião particular do juiz" e, dessa forma, "viver-se-ia na sociedade sem saber precisamente os compromissos nela assumidos" 12 . O método de aplicação do direito nesse modelo de Estado, portanto, é o dedutivo através de um "silogismo subsuntivo" e não existia espaço para os equivalentes jurisdicionais.

O dever do juiz de justificar a decisão é meramente interno, ou seja, a decisão deve ser coerente com o sistema de direito ${ }^{13}$, que aqui é considerado apenas como a lei. Por outras palavras, a legalidade é condição necessária e suficiente para a validade da regra ${ }^{14}$. A base do direito é a abstração e a generalidade da lei. Assim, também, o acesso à justiça, parafraseando Mauro Cappelletti e Bryant Garth ${ }^{15}$, era apenas formal, mas não efetivo, correspondendo a uma igualdade apenas formal.

Tais considerações espelham, exatamente, a ideologia do Estado Liberal que liga liberdade política à certeza do direito ${ }^{16}$. Nas palavras de Luiz Guilherme Marinoni ${ }^{20}$, “a segurança psicológica do indivíduo - ou sua liberdade política - estaria na certeza de que o

\footnotetext{
${ }^{10}$ OST, François. Júpter, Hércules, Hermes: Tres modelos de Juez. Obj. de ref. p. 170, 174 e 175.

${ }^{11}$ MONTESQUUIEU. Do espírito das leis. São Paulo: Abril Cultural, 1973. Obj. de citação p. 158.

${ }^{12}$ MONTESQUIEU. Do espírito das leis. São Paulo: Abril Cultural, 1973. Obj. de citação p. 160. Disse ainda Montesquieu: "não haverá também liberdade se o poder de julgar não estiver separado do poder legislativo e do poder executivo. Se estivesse ligado ao poder legislativo, o poder sobre a vida e a liberdade dos cidadãos seria arbitrário, pois o juiz seria legislador. Se estivesse ligado ao poder executivo, o juiz poderia ter a força de um opressor". (Objeto de citação p. 157)

${ }^{13}$ LUCHI, José Pedro. A racionalidade das decisões jurídicas segundo Habermas. In: Ajuris: Revista da Associação dos Juízes do Rio Grande do Sul. Porto Alegre, ano XXXIV, nº 107, pp. 157-170, setembro de 2007.

${ }^{14}$ OST, François. Júpter, Hércules, Hermes: Tres modelos de Juez. Obj. de ref. p. 178.

${ }^{15}$ CAPPELLETTI, Mauro; GARTH, Bryant. Acesso à Justiça. Trad. Ellen Gracie Northfleet. Porto Alegre: Sergio Antonio Fabris Editor, 1988, reimpresso 2002. Obj. de ref. p. 9.

${ }^{16}$ Cf. TARELLO, Giovanni. Storia della cultura giuridica moderna. Bologna: Il Mulino, 1976. Obj. de citação p. 280. 20 MARINONI, Luiz Guilherme. Do processo civil clássico à noção de direito a tutela adequada ao direito material e à realidade social. Disponível na Internet: <http://www.mundojuridico.adv.br>. Acesso em 08 de novembro de 2006.
} 


\section{Quaestio Iuris}

julgamento apenas afirmaria o que está contido na lei”. A busca do positivismo é pela segurança jurídica, mas não se pode perder de vista que o excesso de positivismo gera o autoritarismo.

Nessa moldura liberal e por percorrer este desencadear de idéias que Montesquieu ${ }^{17}$ definiu o juiz como a bouche de la loi (a boca da lei), concluindo, no seu célebre "Do espírito das Leis", que os juízes de uma nação não são "mais que a boca que pronuncia as sentenças da lei, seres inanimados que não podem moderar nem sua força nem seu rigor”.

Assim, pode-se concluir que o juiz do Estado Liberal possui como dever fundamental a imparcialidade em sentido formal. Ele deve, além disso, policiar o processo evitando desvios do modelo abstrato previsto na lei.

Nas palavras de Ost ${ }^{18}$, Júpiter é "o homem da lei”. Nesse Estado, o juiz adota uma posição passiva diante do caso, ele não atua na busca da verdade somente fiscaliza a relação processual. É um juiz “mínimo” tal qual o Estado Liberal, um mero longa manus da lei.

Sendo assim, a pacificação dos conflitos por um método dialógico de compreensão e cooperação entre as partes, que, como veremos, é a proposta da mediação, não tinha qualquer espaço no referido modelo, o qual buscava a solução dos conflitos no reflexo da legislação prévia e abstrata sobre os fatos, tal qual se vê uma imagem em um espelho ou uma fotografia; não existia, assim, margem para discricionariedade.

Frente a esta conformação, além de ser a jurisdição a única forma de solução das lides, não se cogita neste sistema em deveres de lealdade, de cooperação na busca da verdade. Exige-se tão somente o cumprimento do procedimento previamente previsto em lei, permitindo-se, desse modo, uma atuação puramente estratégica das partes no processo.

Vale dizer que, uma vez driblada a formalidade do procedimento, o participante da relação processual via-se livre de qualquer amarra; não existiam mecanismos de equilíbrio da relação processual. O modelo do Estado Liberal é, pois, subordinado a uma racionalidade instrumental, segundo a qual o próprio direito serve aos fins daquele que institui a lei.

Contudo, não obstante o predomínio do Estado Liberal desde o fim do Estado Soberano, no início do séc. XX, com a revolução comunista russa, iniciada em Moscou em 1917, surge uma grave ameaça à existência da ordem liberal capitalista da Europa.

Foi, pois, diante da ameaça do "fantasma comunista", e frente aos diversos movimentos sociais no âmbito interno, que os Estados europeus perceberam a necessidade da realização de

\footnotetext{
${ }^{17}$ MONTESQUIEU. Do espírito das leis. São Paulo: Abril Cultural, 1973. Obj. de citação p. 160.

${ }^{18}$ OST, François. Júpter, Hércules, Hermes: Tres modelos de Juez. Obj. de ref. p. 177.
} 


\section{Quaestio Iuris}

concessões de caráter assistencial aos seus cidadãos para afastar a possibilidade de uma revolução.

Assim, o Estado Social não tem por finalidade apenas garantir uma esfera de proteção ao indivíduo frente a sua atuação; ele deve garantir mais; deve assegurar não só as liberdades clássicas mas também os efetivos mecanismos para o seu desfrute e exercício. A atividade estatal deixa de ser omissiva para ser comissiva.

O papel preponderante do Estado Social é o fazer. Deve ser garantido ao individuo além de sua vida, de sua propriedade e de sua liberdade, direitos como saúde, educação, lazer, trabalho, moradia, seguridade social, etc. Se no Estado Liberal a ótica era a de uma igualdade formal, neste modelo a busca é por uma igualdade substancial ou real.

A base jurídica deste Estado, portanto, não pode ser a rígida e cega base do positivismo clássico. A realização de fins sociais exige um direito mais flexível, adaptável às diferentes realidades fáticas, atento as particularidades do caso concreto.

O agigantamento estatal, a atuação sobre a economia e a adoção de uma Constituição que é um verdadeiro projeto social, exigem um sistema jurídico dinâmico, um sistema aberto de regras, princípios e valores. Neste modelo, ao contrário de um monismo normativo e político, têm-se um pluralismo de fontes diretas do direito e um pluralismo de poderes competentes para emaná-lo.

Diante dessas enormes diferenças entre o presente modelo e o Estado Liberal, não é difícil compreender a guinada de cento e oitenta graus que a atividade jurisdicional e a atuação do juiz sofreram no Estado Social.

Assim, o modelo jurisdicional aqui é fruto do pensamento realista e da jurisprudência sociológica norte-americana. O direito tem por base a jurisprudência ${ }^{19}$, a decisão do caso concreto. É um direito materializado ${ }^{20}$. A figura que representa este modelo é a de um funil (pirâmide invertida).

Não se utiliza mais a dedução do direito a partir de uma "norma fundamental". Igualmente, não é possível nesse sistema aberto utilizar-se de um simples "silogismo subsuntivo" na aplicação do direito. O juiz passa a ter o dever de confrontação de valores e faz-se necessário

\footnotetext{
${ }^{19}$ OST, François. Júpter, Hércules, Hermes: Tres modelos de Juez. Obj. de ref. p. 170.

${ }^{20}$ HABERMAS, Jürgen. Direito e Democracia: entre facticidade e validade. Vol. I. Tradução: Flávio Beno Siebeneichler. Rio de Janeiro: Tempo Brasileiro, 1997. Obj. de ref. p. 242.
} 


\section{Quaestio Iuris}

recorrer a outros recursos como a ponderação de princípios e a adoção de critérios de proporcionalidade e razoabilidade nas decisões.

O raciocínio neste paradigma também é o inverso daquele do modelo do Estado Liberal, ou seja, a determinação do direito tem origem em uma indução. $\mathrm{O}$ direito é construído não a partir de uma norma geral e abstrata, mas das várias decisões judiciais dos casos concretos.

As bases do direito são a singularidade e a concreção de cada caso. É por isso que Dworkin $^{21}$ propõe uma reconstrução crítica-racional do sistema de direitos na busca pela decisão correta de cada caso. O direito passa a ser visto como instrumento de realização de objetivos políticos $^{22}$. Este modelo liga-se a idéia de efetividade e é desformalizado.

O Juiz Hércules, portanto, é um engenheiro social ${ }^{23}$. Sua posição torna-se mais ativa, embora ainda acima e eqüidistante das partes. Nesse modelo o juiz é quem diz o direito; é um juiz prestacionista e paternalista, tal qual o Estado Social.

No entanto, não obstante todo este agigantamento da figura do juiz, não foram estruturalmente alterados os deveres e prerrogativas dos demais participantes da relação processual sob a égide do Estado Social e nem estimulado o desenvolvimento dos equivalentes jurisdicionais.

É sabido que dentre as causas da crise e posterior falência deste Estado estão a corrupção, a aplicação do sistema administrativo do Estado Liberal e a falta de participação, controle e parceria por parte dos cidadãos. Esta constatação não é diferente em relação ao modelo judicial e aos métodos de pacificação de conflito. O princípio monológico ${ }^{24}$ que rege a atuação do juiz e a atividade jurisdicional prestada pelo Estado reduzem os direitos e deveres dos demais atores processuais.

É ao juiz, representante do Estado Paternalista, que cabe toda a construção da decisão. Tal qual no Estado Liberal, não se cogitava em deveres de lealdade, de cooperação ou no direito de participação no desenvolvimento da marcha processual. No modelo de Estado Social cabe a este, e exclusivamente a este, a entrega do direito e a pacificação dos conflitos.

\footnotetext{
${ }^{21}$ HABERMAS, Jürgen. Direito e Democracia: entre facticidade e validade. Vol. I. Tradução: Flávio Beno Siebeneichler. Rio de Janeiro: Tempo Brasileiro, 1997. Obj. de ref. p. 260.

${ }^{22}$ LUCHI, José Pedro. A racionalidade das decisões jurídicas segundo Habermas. In: Ajuris: Revista da Associação dos Juízes do Rio Grande do Sul. Porto Alegre, ano XXXIV, nº 107, pp. 157-170, setembro de 2007.

${ }^{23}$ OST, François. Júpter, Hércules, Hermes: Tres modelos de Juez. Obj. de ref. p. 177.

${ }^{24}$ Sobre a crítica ao princípio monológico ver HABERMAS, Jürgen. Direito e Democracia: entre facticidade e validade. Vol. I. Tradução: Flávio Beno Siebeneichler. Rio de Janeiro: Tempo Brasileiro, 1997. Obj. de ref. pp. 276280 .
} 
Além disso, se o modelo liberal peca pela ineficiência e distanciamento da realidade; o modelo social vincula demasiadamente a elaboração do direito à figura de um juiz solipsista, impossibilitando a presença da segurança jurídica, fazendo com que o direito perca sua principal função que é a de estabilização social na medida em que cristaliza as expectativas de comportamento $^{25}$.

Se o excesso de positivismo, como já se disse, leva ao autoritarismo, o excesso de realismo gera a arbitrariedade. E, sendo assim, embora por razões opostas ao modelo de Estado Liberal, mas da mesma forma, na mesma intensidade e com o mesmo grau de incompatibilidade institucional, um método dialógico de compreensão e cooperação entre as partes, tal qual é a mediação, não possui lugar no Estado Social.

Portanto, diante da tarefa hercúlea assumida pelo Estado Social, sua atuação demonstrouse fadada ao fracasso. Constatou-se que sem uma participação social efetiva e sem a existência de uma parceria com a esfera privada ocorre a falência da esfera pública, formando-se, ainda, um direito ilegítimo, e revelando-se impossível uma real pacificação social.

Esta mesma crítica é feita ao modelo de jurisdição decorrente dessa sistemática. Verificamos a impossibilidade fática do juiz promover uma reconstrução racional do sistema de direitos. Questionamos a "solidão de uma construção teórica empreendida monologicamente" 26 por Hércules.

A proposta de solução do Estado Democrático de Direito, pois, é pela busca de uma efetiva participação dos consociados jurídicos na realização dos fins estatais. Esta proposta representa para o sistema de pacificação dos conflitos a necessidade de interação entre as partes que compõem a relação processual no âmbito da jurisdição, além da adoção de métodos nãojurisdicionais de solução das lides (autocomposição, mediação etc.).

Nesse sentido falamos no dever de cooperação entre as partes. Nesse modelo prega-se a adoção de um "procedimento argumentativo da busca cooperativa da verdade" ${ }^{27}$. Desse modo, o

\footnotetext{
${ }^{25}$ HABERMAS, Jürgen. Direito e Democracia: entre facticidade e validade. Vol. I. Tradução: Flávio Beno Siebeneichler. Rio de Janeiro: Tempo Brasileiro, 1997. Obj. de ref. pp. 72, 242, 246250.

${ }^{26}$ HABERMAS, Jürgen. Direito e Democracia: entre facticidade e validade. Vol. I. Tradução: Flávio Beno Siebeneichler. Rio de Janeiro: Tempo Brasileiro, 1997. Obj. de citação p. 277.

${ }^{27}$ HABERMAS, Jürgen. Direito e Democracia: entre facticidade e validade. Vol. I. Tradução: Flávio Beno Siebeneichler. Rio de Janeiro: Tempo Brasileiro, 1997. Obj. de citação p. 283.
} 
peso da reconstrução jurídica, que no modelo do Estado Social deve ser suportado por um juiz Hércules, é deslocado para uma comunidade deliberante ${ }^{28}$.

Em relação a uma mudança de mentalidade entre os juízes italianos que vai ao encontro de um modelo do Estado Democrático, Calamandrei ${ }^{29}$ já se manifestou nos seguintes termos:

\begin{abstract}
"Certos juízes, ligados à tradição, crêem que, para melhor conservarem a sua dignidade e a sua autoridade defronte dos advogados, seja indispensável assumirem na sua função uma impassível solenidade de ídolos: colocando entre si e os defensores um diafragma de incompreensão e de fatuidade; mas que 'por sorte' são na Itália cada vez mais numerosos os magistrados que sentem a necessidade e têm a coragem de romper esta barreira de desconfiança e de tomar parte ativa no debate, sem terem medo de cortar ao meio a alegação do defensor para lhe propor quesitos e objeções e para o trazerem à discussão as questões essenciais da causa. Estes são os magistrados que verdadeiramente entendem as exigências modernas da sua função; os advogados deveriam estar particularmente gratos a estes juízes que ousam romper a regra monástica do seu silêncio para transformarem a audiência, de inútil solilóquio de um retórico em face de uma assembléia de sonolentos, num diálogo entre interlocutores vivos que procuram, através da discussão, compreender-se e convencer-se. Importa ainda aqui, para que as instituições judiciárias correspondam às exigências de uma sociedade de homens livres, que seja abolido o seu tradicional caráter secreto, e deixar que também no processo circule entre magistrados e advogados este sentido de confiança, de solidariedade e de humanidade que é em todos os campos o espírito animador da democracia".
\end{abstract}

De outro lado, passando de uma perspectiva de simples validade jurídica para uma perspectiva da união entre validade e legitimidade do direito como condição de sua eficácia e cumprimento de sua função sócio-integradora, o dever do juiz de justificar sua decisão também se altera. Passa-se de um dever de justificação interno, representado pela coerência da decisão com o sistema de direitos para um dever que ao mesmo tempo é interno e externo, este último considerado como a necessidade de legitimação procedimental-deliberativa das premissas prédadas à decisão, o que no caso de um equivalente jurisdicional como a mediação já é condição prévia para seu estabelecimento.

Cabe destacar, ainda, que no modelo democrático, tal qual no modelo de Estado Social, o direito é visto como sistema aberto: "as criações normativas emanam de outras fontes como a

\footnotetext{
${ }^{28}$ LUCHI, José Pedro. A racionalidade das decisões jurídicas segundo Habermas. In: Revista da Ajuris. Porto Alegre, ano XXXIV, no 107, pp. 157-170, setembro de 2007.

${ }^{29}$ CALAMANDREI, Piero, apud VAZ, Alexandre Mário Pessoa. Poderes e Deveres do Juiz na Conciliação Judicial. Vol. I, Tomo I. Coimbra: Coimbra Editora, 1976. Obj. de citação p. 514.
} 
jurisprudência, os costumes, as convenções internacionais, os princípios gerais do direito, a doutrina etc." 30 .

O direito pós-moderno de Hermes "é uma estrutura em rede que se traduz em infinitas informações disponíveis instantaneamente e, ao mesmo tempo, dificilmente matizáveis, tal como pode ser um banco de dados". O presente modelo é uma dialética entre transcendência e imanência ${ }^{31}$. A proposta é de uma "teoria do direito como circulação de sentido", "um processo coletivo, ininterrupto e multidirecional de circulação do logos jurídico" ${ }^{32}$.

Vale recordar que Hermes é o deus da comunicação, da circulação, da intermediação; é um interprete, um mediador, um porta-voz. A idéia é a de que o direito, como signo lingüístico que ontologicamente é, sempre necessita de interpretação e, portanto, é inacabado; permanece continuamente se realizando (caráter hermenêutico ou reflexivo do juízo jurídico).

Portanto, o direito em um Estado Democrático é líquido e denso ao mesmo tempo. Convém mencionar que o correspondente latino de Hermes (grego) é Mercúrio, representado hoje por um metal de alta densidade que, não obstante, encontra-se no estado líquido. Esta "liquidez jurídica" se dá por meio da equidade e permite ao direito preencher os buracos nas relações sociais. "Somente a lei mesma de circulação do discurso jurídico pode aclarar sua gênesis e seu desenvolvimento. [...] Antes de ser regra de instrução, o direito é razão (logos), discurso, significado em suspenso" ${ }^{33}$.

Esta capacidade de integração social, contudo, só pode ser obtida por uma legitimidade de duplo aspecto. Em um primeiro momento, pela obediência a um procedimento que eleva o dissenso para promover o consenso ${ }^{34}$. Vejam-se as palavras de $\mathrm{Ost}^{35}$ :

"Seja qual for o conteúdo material das soluções que se impõe, o direito é antes de tudo um procedimento de discussão pública razoável, um modo de solução de conflitos eqüitativo e contraditório. [...] A primeira garantia de legitimidade reside no respeito às condições da discussão sem coação. Esse respeito às formas, aos prazos, aos procedimentos é realmente essencial e consubstancial ao direito".

\footnotetext{
${ }^{30}$ OST, François. Júpter, Hércules, Hermes: Tres modelos de Juez. Obj. de citação nota de rodapé 3.

${ }^{31}$ OST, François. Júpter, Hércules, Hermes: Tres modelos de Juez. Obj. de ref. p. 172.

32 OST, François. Júpter, Hércules, Hermes: Tres modelos de Juez. Obj. de citação p. 181-182.

${ }^{33}$ OST, François. Júpter, Hércules, Hermes: Tres modelos de Juez. Obj. de citação p. 187.

${ }^{34}$ LUCHI, José Pedro. A racionalidade das decisões jurídicas segundo Habermas. In: Ajuris: Revista da Associação dos Juízes do Rio Grande do Sul. Porto Alegre, ano XXXIV, no 107, pp. 157-170, setembro de 2007.

${ }^{35}$ OST, François. Júpter, Hércules, Hermes: Tres modelos de Juez. Obj. de citação p. 190.
} 
A mediação procedimental, no entanto, não constitui toda a legitimidade do direito. É preciso se estabelecer um laço necessário entre o respeito ao procedimento e os direitos fundamentais $^{36}$. O que constitui, precisamente, a idéia de um formalismo valorativo que deve abranger ao menos quatro valores fundamentais: segurança jurídica, participação, liberdade e efetividade ${ }^{37}$.

O núcleo central desse modelo, portanto, é o discurso (racionalidade comunicativa) e a participação. E é exatamente por isso que não só se torna possível, mas necessária a adoção de mecanismos de pacificação dos conflitos cujo foco principal esteja nas partes e não no Estado juiz, tal qual é a mediação, nitidamente mais participativa e dialógica em relação à jurisdição.

No âmbito desta última, porém, o juiz Hermes deve, igualmente, apresentar-se como um mediador da relação entre as partes, deve buscar a todo o momento a conciliação, deve garantir a interação, a cooperação, a lealdade e a boa-fé de todos os participantes do processo.

Possui, também, o dever de equilibrar a relação processual. Sua atuação constitui-se um meio termo entre a inércia de Júpiter e o egocentrismo de Hércules. O juiz do presente modelo é mais humano, reconhece suas limitações e busca apoio nos interessados pelos desfeche da relação processual. Verifica-se, pois, que a superação do princípio monológico que rege a atuação do juiz Hércules é exatamente pelo fato de que o mesmo afasta a idéia de cooperação como condição para o desenvolvimento de um procedimento de bases racional, discursiva e valorativa de determinação da justiça no caso concreto ${ }^{38}$. E tal superação, em verdade, deve ser

\footnotetext{
${ }^{36}$ OST, François. Júpter, Hércules, Hermes: Tres modelos de Juez. Obj. de ref. p. 191. Luiz Guilherme Marinoni, a seu turno, afirma que "[...] os direitos fundamentais podem ser vistos não apenas como a substância que orienta o modo de ser do ordenamento jurídico, mas também como as ferramentas que servem para a (i) interpretação de acordo, para a (ii) eliminação da lei inconstitucional (declaração de inconstitucionalidade da lei), para a (iii) adequação da lei à Constituição (interpretação conforme e declaração parcial de nulidade sem redução do texto), para a (iv) geração da regra necessária para que o direito fundamental seja feito valer (controle da omissão inconstitucional) e para a (v) proteção de um direito fundamental diante de outro (aplicação da regra do balanceamento)". MARINONI, Luiz Guilherme. A Jurisdição no Estado Contemporâneo. In: ___ (Coord.). Estudos de Direito Processual Civil: homenagem ao Professor Egas Dirceu Moniz de Aragão. São Paulo: Revista dos Tribunais, 2005, pp. 13-66. Obj. de citação p. 51.

${ }^{37}$ Para um estudo sobre o formalismo-valorativo ver: OLIVEIRA, Carlos Alberto Alvaro. O formalismo-valorativo no confronto com o formalismo excessivo. In: DIDIER JR., Fredie (Org.). Leituras Complementares de Processo Civil. $5^{a}$ ed. rev. atu. Salvador: Juspodivm, 2007, pp. 351-372. Conferir também: OLIVEIRA, Carlos Alberto Álvaro de. Do formalismo no processo civil. $2^{\mathrm{a}}$ ed. rev. São Paulo Saraiva, 2003.

${ }^{38}$ Luiz Guilherme Marinoni, tratando das repercussões da transformação do direito sobre a figura do juiz, ensina: "O juiz não é mais a boca da lei, como queria Montesquieu, mas sim o projetor de um direito que toma em consideração a lei à luz da Constituição e, assim, faz os devidos ajustes para suprir as suas imperfeições ou encontrar uma interpretação adequada, podendo chegar a considerá-la inconstitucional no caso em que a sua aplicação não é possível diante dos princípios de justiça e dos direitos fundamentais". MARINONI, Luiz Guilherme. Curso de Processo Civil: Teoria Geral do Processo. Vol. 1. São Paulo: Revista dos Tribunais, 2006. Obj. de citação p. 54.
} 


\section{Quaestio Iuris}

buscada tanto no interior da própria jurisdição como por métodos não-jurisdicionais de pacificação social, tal qual é a mediação.

Pregamos, pois, tal qual François Ost ${ }^{43}$, que diante da complexidade dos casos sociais, do desenvolvimento científico e da globalização, é necessário um resgate da velha regra de "prudência" da qual certo direito extrai seu nome. E a institucionalização da prudência se dá exatamente por meio do procedimento e dos equivalentes jurisdicionais.

Isso porque, se de um lado o processo não pode ser organizado arbitrariamente pelo legislador, nem arbitrariamente conduzido pelo juiz sendo dependente do direito material, da Constituição e dos valores, de outro, a jurisdição tem diversos limites em sua atuação social, notadamente sobre o ponto de vista de uma solução legítima e efetiva de muitos dos conflitos a ela submetidos.

Ademais, como ressaltou Ascensão José de Oliveira ${ }^{44}$ : "O direito não é uma ordem estática e acabada. É antes dinâmica, porque necessariamente se manifesta na ação. E também a ação jurídica, como toda ação, deve ser comandada pela prudência - a prudência romana ou a phronesis dos gregos. [...] O direito aparece-nos assim à partida como uma dialética da ordem e da prudência".

Pois bem, fixadas tais premissas fundamentais e indispensáveis ao enquadramento contemporâneo do sistema de direitos e da jurisdição, bem como demonstrada a importância e a

necessidade de métodos alternativos de solução de conflitos para se atingirem os escopos do Estado Democrático-deliberativo de Direito, cabe, como próximo passo, ingressarmos em uma investigação de caráter dogmático da mediação, buscando compreender suas especificidades ao mesmo tempo em que almejamos proceder a uma análise crítica de alguns dos pontos polêmicos sobre o tema.

Como já afirmado, neste ano de 2008 o Projeto de Lei 4.827 completa dez anos de tramitação, tendo recebido diversas redações e suscitado um interminável debate sobre o instituto da mediação entre os mais variados setores da sociedade civil.

Não obstante ainda não ter se convertido formalmente em Lei, é preciso que se diga que a mediação está largamente difundida no Brasil e já é exercida inclusive dentro dos órgãos do 


\section{Quaestio Iuris}

Poder Judiciário, na medida em que se funda na livre manifestação de vontade das partes e na escolha por um instrumento mais profundo de solução do conflito ${ }^{39}$.

Nesse sentido, na mediação não se busca uma decisão que ponha um ponto final na controvérsia, até mesmo porque o mediador não tem poder decisório, o que, desde logo, o difere do árbitro.

O que se procura é a real pacificação do conflito por meio de um mecanismo de diálogo (discurso racional) $^{40}$, compreensão e ampliação da cognição das partes sobre os fatos que as levaram àquela disputa.

Nessa parte do trabalho, pois, vamos procurar apresentar alguns institutos da mediação e comentar dispositivos do Projeto de Lei que consideramos sejam, ainda, merecedores de maior reflexão.

Nessa linha de raciocínio, entendemos a mediação, numa definição bastante singela, como o instrumento de solução de um conflito, por meio do qual os litigantes buscam o auxílio de um terceiro imparcial, e que seja detentor de sua confiança.

Esse terceiro, como visto, não tem a missão de decidir (e nem a ele foi dada autorização para tanto); e é justamente isso que faz com que as partes procurem o mediador e exponham de forma mais sincera os seus problemas. Cabe ao mediador auxiliá-las na obtenção da solução consensual, fazendo com que elas enxerguem os obstáculos ao acordo e possam removê-los de forma consciente, como verdadeira manifestação de sua vontade e de sua intenção de compor o litígio como alternativa ao embate.

Normalmente, ao fim de um procedimento exitoso de mediação, as partes compreendem que a manutenção do vínculo que as une é mais importante do que um problema circunstancial e, por vezes, temporário. Como explicaremos mais adiante, a mediação é o método de solução de controvérsias ideal para as relações duradouras, como é o caso de cônjuges, familiares, vizinhos e colegas de trabalho, entre outros.

Na mesma linha, ao tratar do tema, Maria de Nazareth Serpa ${ }^{47}$, define mediação como "um processo informal, voluntário, onde um terceiro interventor, neutro, assiste aos disputantes na

\footnotetext{
${ }^{39}$ Projeto "Movimento pela Conciliação" liderado pelo Conselho Nacional de Justiça e coordenado por Lorenzo Lorenzoni e Germana Moraes, disponível no sítio http://www.cnj.gov.br, acesso em 15 de abril de 2008.

${ }^{40}$ Habermas, ao cuidar do discurso racional, afirma: "E "discurso racional" é toda a tentativa de entendimento sobre pretensões de validade problemáticas, na medida em que ele se realiza sob condições da comunicação que permitem o movimento livre de temas e contribuições, informações e argumentos no interior de um espaço público constituído através de obrigações ilocucionárias." HABERMAS, Jürgen. Direito e Democracia: entre facticidade e validade. Vol. I. Tradução Flávio Beno Siebeneichler. Rio de Janeiro: Tempo Brasileiro, 1997. Obj. de citação p. 142.
} 


\section{Quaestio Iuris}

vol.04, n0.01. ISSN 1516-0351

resolução de suas questões". ${ }^{41}$ Sendo que o papel desse interventor é ajudar na comunicação através da neutralização de emoções, formação de opções e negociação de acordos.

Como agente fora do contexto conflituoso, funciona como um catalisador de disputas, ao conduzir as partes às suas soluções, sem propriamente interferir na substância destas.

José Maria Rossani Garcez ${ }^{42}$ afirma que a mediação terá lugar quando, devido à natureza do impasse, quer seja por suas características ou pelo nível de envolvimento emocional das partes, fica bloqueada a negociação, que assim, na prática, permanece inibida ou impedida de se realizar. Realmente, a tendência natural das pessoas é a de tentar resolver o problema por si mesmas, sem o auxílio de terceiros. Por vezes, contudo, tal estratégia acaba por tornar o conflito ainda mais intenso e afastar a solução que não pôde ser enxergada pelas partes dado o seu envolvimento emocional.

Ainda na perspectiva conceitual, Roberto Portugal Bacellar ${ }^{49}$ define mediação como uma "técnica lato senso que se destina a aproximar pessoas interessadas na resolução de um conflito a induzi-las a encontrar, por meio de uma conversa, soluções criativas, com ganhos mútuos e que preservem o relacionamento entre elas".

Normalmente essas pessoas, após um fracassado processo de negociação, chegam à conclusão de que não são capazes, por elas próprias, de remover os obstáculos que impedem a celebração do acordo ${ }^{50}$. Buscam, num terceiro, o auxílio para desobstruir a via do consenso, que sabem existir, embora não sejam capazes de encontrá-la ${ }^{43}$.

Mas é possível também, e é preciso que se advirta dessa possibilidade, que a via consensual esteja irremediavelmente comprometida, por conta um relacionamento já desgastado pelo tempo, pelas intempéries de uma ou ambas as partes e ainda pela falta de habilidade em lidar com o

\footnotetext{
${ }^{41}$ SERPA, Maria de Nazareth. Teoria e Prática da Mediação de Conflitos, Rio de Janeiro: Lumen Juris, 1999 , p. 90.

${ }^{42}$ GARCEZ, José Maria Rossani. Negociação. ADRS. Mediação. Conciliação e arbitragem. $2^{a}$ ed. Rio de Janeiro:

Lumen Juris, 2003. Obj. de ref. p. 35. 49

BACELLAR, Roberto Portugal. Juizados especiais - a nova mediação paraprocessual. São Paulo: Revista dos Tribunais. Obj. de citação p. 174. 50 No mesmo sentido, Maria de Nazareth Serpa afirma que a mediação é um "processo onde e através do qual uma terceira pessoa age no sentido de encorajar e facilitar a resolução de uma disputa sem prescrever qual a solução. Um de seus aspectos-chave é que incorpora o uso de um terceiro que não tem nenhum interesse pessoal no mérito das questões. Sem essa intervenção neutra, as partes são incapazes de engajar uma discussão proveitosa. $\mathrm{O}$ terceiro interventor serve, em parte, de árbitro para assegurar que o processo prossiga efetivamente sem degenerar em barganhas posicionais ou advocacia associada”. Obj. de citação p. 147.

${ }^{43}$ Afirma João Roberto da Silva que "a base do processo de mediação é a visão positiva do conflito. A ciência desta ensina o conflito como algo necessário para o aperfeiçoamento humano, seja pessoal, comercial, tecnológico, ou outro qualquer, pois, quando considera a concepção de realidade não traça um ser mediano e repleto de retidão. Para a mediação frente a análise de realidade não há ninguém normal ou anormal, somente se tem diferentes modelos de realidade”. SILVA, João Roberto da. A mediação e o processo de mediação. São Paulo: Paulistanajur Edições, 2004. Obj. de citação p. 15.
} 


\section{Quaestio Iuris}

conflito, daí propormos a mediação como alternativa complementar e não substitutiva à jurisdição ou à arbitragem.

Isso porque, nesses casos, deve se recorrer à adjudicação ou decisão forçada, hipótese em que um terceiro deverá, após se certificar que não há mais possibilidade de acordo, emitir um juízo de valor acerca da situação concreta na qual os interesses das partes estão contrapostos. E a referida adjudicação vai assumir, basicamente, a forma de arbitragem ou de jurisdição. E aqui precisamos deixar um ponto bem claro: assim como a jurisdição, conforme já afirmamos, tem os seus limites (examinada num plano de efetividade, enquanto meio de solução de controvérsias), ou seja, não é o meio mais indicado para conflitos que envolvem relações continuadas com forte componente emocional; também a mediação tem lá suas fronteiras, as quais não devem ser negligenciadas.

Em outras palavras, é um erro pensar na mediação como a panacéia para todos os males, até porque, sua premissa básica é a voluntariedade e a boa fé de seus atores. E aqui vai nossa primeira crítica concreta ao Projeto de Lei; a mediação não deve ser utilizada indiscriminada e genericamente em todos os procedimentos civis. Deve haver um mecanismo de filtragem, de modo a que a mediação seja utilizada, apenas, nas hipóteses nas quais possa ser útil.

Prosseguindo em nossas considerações gerais, podemos dizer que três são os elementos básicos para que possamos ter um processo de mediação: a existência de partes em conflito, uma clara contraposição de interesses e um terceiro neutro capacitado a facilitar a busca pelo acordo. Com relação às partes, podem ser elas pessoas físicas ou jurídicas. Podem ser também entes despersonalizados, desde que se possa identificar seu representante ou gestor. Podem ser ainda menores, desde que devidamente assistidos por seus pais (veja-se, por exemplo, a utilidade da mediação em conflitos juvenis e escolares e a sua potencialidade como instrumento de prevenção ao envolvimento de adolescentes com atividades criminosas, uma das áreas mais profícuas para a chamada "justiça restaurativa").

O segundo elemento, conflito, delimita a amplitude da atividade a ser desenvolvida pelo mediador. É preciso deixar claro que a mediação não se confunde com um processo terapêutico ou de acompanhamento psicológico ou psiquiátrico.

É certo que é extremamente desejável que o profissional da mediação tenha conhecimentos em psicologia e, sobretudo, prática em lidar com as relações humanas e sociais. Contudo, deve haver um limite claro para a sua intervenção, sob pena de se perder o foco e tornar o processo abstrato, interminável e, portanto, infrutífero.

Revista Quaestio Iuris, vol.04, n01. ISSN 1516-0351 p.245-277 260 
Por fim, o mediador deve ser neutro, eqüidistante das pessoas envolvidas no litígio e que goze de boa credibilidade. Deve ser alguém apto a interagir com elas, mostrar-se confiável e disposto a auxiliar concretamente no processo de solução daquele conflito.

Para Nuria Belloso Martín ${ }^{44}$, a mediação se caracterizará sempre pelos seguintes elementos: a) voluntariedade; b) eleição do mediador; c) aspecto privado; d) cooperação entre as partes; e) conhecimentos específicos (habilidade) do mediador; f) reuniões programadas pelas partes; g) informalidade; h) acordo mútuo; i) ausência de sentimento de vitória ou derrota.

Desse modo, via de regra, a mediação é um procedimento extrajudicial e ocorre, como visto acima, antes da procura pela adjudicação. Contudo, nada impede que as partes, já tendo iniciado a etapa jurisdicional, resolvam retroceder em suas posições e tentar, uma vez mais, a via conciliatória.

Não custa enfatizarmos que o melhor modelo, a nosso ver, é aquele que admoesta as partes a procurarem a solução consensual, com todas as suas forças, antes de ingressarem com a demanda judicial. É desnecessário ter um sistema de mediação incidental muito bem aparelhado, eis que já terá havido a movimentação da máquina judiciária, quando, em muitos dos casos, isto poderia ter sido evitado.

Somos de opinião que as partes deveriam ter a obrigação de demonstrar ao Juízo que tentaram, de alguma forma, buscar uma solução consensual para o conflito.

Não obstante, entendemos, de outro lado, que também não há necessidade de uma instância prévia formal extrajudicial, como ocorre com as Comissões de Conciliação Prévias na Justiça do Trabalho; basta algum tipo de comunicação, como o envio de uma carta ou e-mail, uma reunião entre advogados, um contato com o "call center" de uma empresa feito pelo consumidor; enfim, qualquer providência tomada pelo futuro demandante no sentido de demonstrar ao Juiz que o ajuizamento da ação não foi sua primeira alternativa.

Estamos pregando aqui uma ampliação no conceito processual de interesse em agir, como forma de racionalizar a prestação jurisdicional e evitar a procura desnecessária pelo Poder Judiciário,

\footnotetext{
${ }^{43}$ OST, François. Júpter, Hércules, Hermes: Tres modelos de Juez. Obj. de ref. p. 193.

ASCENSÃO, José de Oliveira. Introdução à ciência do Direito. $3^{\text {a }}$ ed. Rio de Janeiro: Renovar, 2005. Obj. de citação pp. 4-5.

${ }^{44}$ MARTín, Nuria Belosso. Reflexiones sobre Mediación Familiar: Algunas Experiencias en el Derecho Comparado. Artigo gentilmente cedido pela autora quando ministrou disciplina no Curso de Mestrado em Direito da UNESA em novembro de 2005.
} 


\section{Quaestio Iuris}

promovendo-se, ademais, uma ampliação de métodos mais democráticos, participativos e até mesmo mais efetivos de solução dos conflitos.

Mas esta é apenas uma das facetas desta visão. A outra e, talvez, a mais importante, seja a consciência do próprio Poder Judiciário de que o cumprimento de seu papel constitucional não conduz, obrigatoriamente, à intervenção em todo e qualquer conflito.

Tal visão pode levar a uma dificuldade de sintonia com o Princípio da Indelegabilidade da Jurisdição, na esteira de que o juiz não pode se eximir de sua função de julgar, ou seja, se um cidadão bate as portas do Poder Judiciário, seu acesso não pode ser negado ou dificultado, na forma do artigo $5^{\circ}$, inciso XXXV da Carta de 1988.

Porém, o que deve ser esclarecido é que o fato de um jurisdicionado solicitar a prestação estatal não significa que o Poder Judiciário deva, sempre e necessariamente, ofertar uma resposta de índole impositiva, limitando-se a aplicar a lei ao caso concreto, tal qual faria o Juiz Júpiter. Pode ser que o Juiz entenda que aquelas partes precisem ser submetidas a uma instância conciliatória, pacificadora, antes de uma decisão técnica, adotando verdadeira postura de um mediador, um pacificador, revestindo-se com as características do Juiz Hermes, tratado acima. E mais, num momento inicial, como é este em que se encontra o direito brasileiro, requer certa dose de postura educativa e pedagógica, a fim de proporcionar a referida circulação do logos jurídico e não apenas um "inútil solilóquio de um retórico", conforme afirmou Calamandrei.

Tal postura, nos termos já propostos acima, não só pode como deve ser incentivado pelo próprio Poder Judiciário ${ }^{45}$. Nesse sentido, vale a pena dar uma olhada no "Alternative Dispute Resolution Act $^{\text {"54 }}$ de 1988, em vigor nos Estados Unidos.

\footnotetext{
${ }^{45}$ Importante deixar clara essa nova dimensão do Poder Judiciário, aparentemente minimalista, numa interpretação superficial, mas que na verdade revela toda a grandeza desta nobre função do Estado. Nessa perspectiva, efetividade não significa ocupar espaços e agir sempre, mas intervir se e quando necessário, como ultima ratio. Veja-se o excerto adiante transcrito da obra de Eligio Resta: "A oferta monopolista de justiça foi então incorporada no interior do sistema da jurisdição, delegado a receber a a regular uma conflitualidade crescente; tecnicamente aquilo que levou a altos graus de ineficiência o sistema da jurisdição foi um crescimento vertiginoso das expectativas e das perguntas a isso referidas. Tecnicametne se chama explosão da litigiosidade, que tem muitas causas, mas que nunca foi analisada de forma mais profunda. É notório como a nossa estrutura jurídico-política foi sempre muito atenta aos remédios (portnto reformas perenes das normas), quase nunca às causas, deixando de lado análises atentas sobre a litigiosidade que cresce, que é constantemetne traduzida na linguagem jurídica e que se dirige à jurisdição sob a forma irrefreável de procedimentos judiciários. (...) Em face de tal hipertrofia, a direção da política do direito, na qual mover-se, me parece que deva ser no sentido de uma jurisdição mínima, contra uma jurisdição tão onívora quanto ineficaz". (RESTA, Eligio [trad. Sandra Vial]. O Direito Fraterno. Santa Cruz do Sul: EDUNISC, 2004. Obj. de citação pp. 99-100). 54 Seguem
} 
A mediação incidental ou judicial já pode ser feita hoje em nosso ordenamento, em duas hipóteses: ou o juiz, ele próprio, conduz o processo, funcionando como um conciliador ou designando um auxiliar para tal finalidade (artigos 331 e 447 do CPC); ou as partes solicitam ao juiz a suspensão do processo, pelo prazo máximo de seis meses, para a efetivação das tratativas de conciliação fora do juízo (artigo 265, inciso II, c/c $\S 3^{\circ}$, também do CPC).

Contudo, nas duas hipóteses, como já frisamos, terá havido a movimentação da máquina judicial (apresentação da petição inicial, recolhimento de custas, despacho liminar positivo, citação do réu, prazo para contestação, diligências cartorárias, resposta do réu e designação de audiência prévia, sem contar com os inúmeros incidentes processuais que podem tornar mais complexa a relação processual).

Voltando à questão da mediação propriamente dita, como já tivemos oportunidade de ressaltar ${ }^{55}$, de acordo com a postura do mediador, podemos classificar o procedimento em ativo ou passivo.

Na mediação passiva o terceiro apenas ouve as partes, agindo como um facilitador ${ }^{56}$ do processo de obtenção de uma solução consensual para o conflito, sem apresentar o seu ponto de vista, possíveis soluções ou propostas concretas às partes.

No caso da mediação ativa, o mediador funcionará como uma espécie de conciliador; ele não se limita a facilitar; terá ele também a função de apresentar propostas, soluções alternativas e

os principais excertos do "Act”: “(...)(2) certain forms of alternative dispute resolution, including mediation, early neutral evaluation, minitrials, and voluntary arbitration, may have potential to reduce the large backlog of cases now pending in some Federal courts throughout the United States, thereby allowing the courts to process their remaining cases more efficiently; (...) (b) AUTHORITY- Each United States district court shall authorize, by local rule adopted under section 2071(a), the use of alternative dispute resolution processes in all civil actions, including adversary proceedings in bankruptcy, in accordance with this chapter, except that the use of arbitration may be authorized only as provided in section 654. Each United States district court shall devise and implement its own alternative dispute resolution program, by local rule adopted under section 2071(a), to encourage and promote the use of alternative dispute resolution in its district. (...) SEC. 4. JURISDICTION. Section 652 of title 28, United States Code, is amended to read as follows: Sec. 652. Jurisdiction (a) CONSIDERATION OF ALTERNATIVE DISPUTE RESOLUTION IN APROPRIATE CASESNotwithstanding any provision of law to the contrary and except as provided in subsections (b) and (c), each district court shall, by local rule adopted under section 2071(a), require that litigants in all civil cases consider the use of an alternative dispute resolution process at an appropriate stage in the litigation. Each district court shall provide litigants in all civil cases with at least one alternative dispute resolution process, including, but not limited to, mediation, early neutral evaluation, minitrial, and arbitration as authorized in sections 654 through 658 . Any district court that elects to require the use of alternative dispute resolution in certain cases may do so only with respect to mediation, early neutral evaluation,

and, if the parties consent, arbitration. (b) ACTIONS EXEMPTED FROM CONSIDERATION OF ALTERNATIVE DISPUTE RESOLUTION- Each district court may exempt from the requirements of this section specific cases or categories of cases in which use of alternative dispute resolution would not be appropriate. In defining these exemptions, each district court shall consult with members of the bar, including the United States Attorney for that district.”. Fonte: http://www.pubklaw.com/hi/105-315.html, acesso em 30 de setembro de 2007. 
criativas para o problema, alertar as partes litigantes sobre a razoabilidade ou não de determinada proposta, influenciando assim o acordo a ser obtido. Aqui o mediador assume posição avaliadora.

Obviamente chegar a um acordo por meio do processo de mediação não é tarefa fácil. Exige tempo, dedicação e preparação adequada do mediador.

Seria um erro grave pensar em executar mediações em série, de forma mecanizada, como hoje, infelizmente, se faz com as audiências prévias ou de conciliação, nos juizados especiais e na Justiça do Trabalho.

A mediação é um trabalho artesanal, que deve ser empreendido com base no diálogo e na cooperação entre as partes, de forma que por meio de tomadas de posição equânimes sejam preenchidas as lacunas existentes em suas relações, atingindo-se um consenso, ou, ao menos, um compromisso leal ${ }^{46}$.

Para fins de se promover a mediação, portanto, cada caso é único. Demanda tempo, estudo, análise aprofundada das questões sob os mais diversos ângulos. O mediador deve se inserir no contexto emocional-psicológico do conflito. Deve buscar os interesses, por trás das posições externas assumidas ${ }^{47}$, para que possa indicar às partes o possível caminho que elas tanto procuravam $^{59}$.

É um processo que pode se alongar por semanas, com inúmeras sessões, inclusive com a participação de co-mediadores, estando as partes, se assim for de seu desejo, assistidas a todo o tempo por seus advogados, devendo todos os presentes anuírem quanto ao procedimento utilizado e à maneira como as questões são postas na mesa para exame (atitude voltada para o entendimento mútuo) $)^{48}$.

\footnotetext{
${ }^{46}$ Vale advertir que um compromisso é um acertamento, uma média entre duas idéias. O conscenso, contudo, exige entendimento mútuo, ou seja, a aceitação dos mesmos argumentos pelas mesmas razões. Nesse sentido, ao diferenciar a moral do direito José Pedro Luchi afirma: “[...] na moral o ponto de vista considerado é apenas aquele mais abstrato de uma resolução de conflitos que possa resultar no que é "bom" para todos os envolvidos, enquanto no Direito se inserem também questões da auto-compreensão da coletividade e, então, dos fins e valores e dos meios para realizá-los. Também deve ser incluído o âmbito dos compromissos negociáveis, onde não há possibilidade de entendimento". LUCHI, José Pedro. A lógica dos Direitos Fundamentais e dos Princípios do Estado. In: Linguagem e Sociabilidade. José Pedro Luchi (org.) Vitória: EDUFES, 2005. Obj. de citação p.143.

${ }_{47}$ FISCHER, Roger and William Ury. Getting to Yes: Negotiating Agreement without Giving In. Boston: Houghton Mifflin Co., 1981. 59

Cf, também, as seguintes obras: CRAVER, Charles B. Effective Legal Negotiation and Settlement. New York: Lexis, 2001; SINGER, Linda R. Settling Disputes. $2^{\text {nd }}$ edition. Colorado: Westview, 1994; e WILLIAMS, Gerald R. Legal Negotiations and Settlement, Minnesota: West, 1983.

${ }^{48}$ Para Habermas: "O acordo no sentido estrito só é então alcançado se os envolvidos podem aceitar uma pretensão de validade pelas mesmas razões, enquanto um entendimento mútuo acontece mesmo quando um vê que o outro, à luz de suas preferências, tem sob circunstâncias dadas boas razões para a intenção declarada, isto é, razões que são boas para ele, sem que o outro precise se apropriar delas à luz de suas próprias preferências". HABERMAS, Jürgen.
} 
Desse modo, o elemento principal para a compreensão da mediação é a formação de uma cultura de pacificação ${ }^{49}$, em oposição à cultura hoje existente em torno da necessidade de uma decisão judicial para que a lide possa ser resolvida.

Nesse sentido, o artigo $1^{\circ}$, na redação atual do Projeto, dispõe de forma inquívoca que a modalidade a ser adotada pelo Brasil será a passiva, dando a entender que a chamada mediação ativa (conciliação) não se coaduna com o espírito do legislador.

Nesse ponto, mister algumas considerações.

A distinção entre mediação e conciliação é tarefa um tanto árdua. Alguns autores recomendam tratar os dois termos como sinônimos. Entretanto, na Itália ${ }^{50}$ os autores traduzem a palavra inglesa mediation para conciliazione, reservando o termo mediazione para a gestão dos conflitos em matéria familiar, social, escolástica e penal. Isto com o objetivo de distinguir claramente a atividade praticada pelo Estado em face da existência ou iminência de um processo (conciliazione), da atividade meramente espontânea de pacificação social, praticada em face da existência de conflitos latentes ou iminentes, mas sem que ainda se tenha cogitado do processo judicial (mediazione).

Porém, considerando que o sistema norte-americano é eminentemente paraprocessual e parajudicial, a proposta brasileira a ele em muito se assemelha. Mantendo a nomenclatura norteamericana, está sendo proposta no Brasil a mediação paraprocessual. Podemos, então, estabelecer três critérios fundamentais:

Quanto à finalidade, a mediação visa resolver abrangentemente o conflito entre os envolvidos. Já a conciliação contenta-se em resolver o litígio conforme as posições apresentadas pelos envolvidos.

Quanto ao método, o conciliador assume posição mais participativa, podendo sugerir às partes os termos em que o acordo poderia ser realizado, dialogando abertamente a este respeito, ao passo que o mediador deve abster-se de tomar qualquer iniciativa de proposição, cabendo a ele apenas assistir as partes e facilitar a sua comunicação, para favorecer a obtenção de um acordo de recíproca satisfação.

Verdade e Justificação: ensaios filosóficos. Tradução Milton Camargo Mota. São Paulo: Edições Loyola, 2004. Obj. de citação p. 115.

${ }^{49}$ WATANABE, Kazuo. Cultura da Sentença e Cultura da Pacificação, in Estudos em Homenagem à Professora Ada Pellegrini Grinover (org. Flávio Luiz Yarchell e Maurício Zanoide de Moraes), São Paulo: DPJ, 2005. Obj. de ref. pp. 684-690.

${ }^{50}$ Conferir, por todos, PINHO, Humberto Dalla Bernardina de [organizador]. Teoria Geral da Mediação à luz do Projeto de Lei e do Direito Comparado. Rio de Janeiro: Lumen Juris, 2008. 


\section{Quaestio Iuris}

vol.04, n0.01. ISSN 1516-0351

Por fim, quanto aos vínculos, a conciliação é uma atividade inerente ao Poder Judiciário, sendo realizada por juiz togado, por juiz leigo ou por alguém que exerça a função específica de conciliador. Por outro lado, a mediação é atividade privada, livre de qualquer vínculo, não fazendo parte da estrutura de qualquer dos Poderes Públicos. Mesmo a mediação paraprocessual mantém a característica privada, estabelecendo apenas que o mediador tem que se registrar no tribunal para o fim de ser indicado para atuar nos conflitos levados à Justiça.

Apesar do acerto do Projeto quanto à opção pela mediação dita passiva, merece crítica o dispositivo que cria uma instância superveniente de conciliação, mesmo após ter sido tentada a mediação em sessão própria, antes ou durante o processo.

Isso se dá pela alteração sugerida pelo Projeto ${ }^{51}$ ao artigo 331 do CPC, no sentido de adotar a “early neutral evaluation" do direito norte-americano no bojo da audiência de conciliação.

Pode-se afirmar que esta inovação está em oposição ao Princípio da Duração Razoável do Processo, consubstanciada no artigo 5 , inciso LXXVIII da Carta de 1988 (inserido pela Emenda Constitucional $\left.n^{\circ} 45 / 04\right)$, uma vez que o procedimento fica "inchado" desnecessariamente.

Como já referimos, o equívoco está em trazer a atividade mediadora para dentro da instância jurisdicional, ao invés de se tentar tal medida em caráter profilático e prévio.

Diante desses elementos, a seguinte indagação se impõe: A mediação é o modo apropriado para resolver aquele conflito entre aquelas partes?

Esta é a pergunta crítica no começo de qualquer mediação, além de ser a pergunta a ser feita durante todo o processo, tanto pelas partes quanto pelo mediador.

O ponto central em determinar a propriedade da mediação reside em saber se as partes podem lidar justamente uma com a outra. Diferenças na abertura das partes para o processo, a tendência

\footnotetext{
${ }^{51}$ Art. 43. O art. 331 e parágrafos da Lei $\mathrm{n}^{\circ}$ 5.869, de 1973, Código de Processo Civil, passam a vigorar com a seguinte redação: “Art. 331. Se não se verificar qualquer das hipóteses previstas nas seções precedentes, o juiz designará audiência preliminar, a realizar-se no prazo máximo de trinta dias, para qual serão as partes intimadas a comparecer, podendo fazer-se representar por procurador ou preposto, com poderes para transigir. $\S 1^{\circ} \mathrm{Na}$ audiência preliminar, o juiz ouvirá as partes sobre os motivos e fundamentos da demanda e tentará a conciliação, mesmo tendo sido realizada a tentativa de mediação prévia ou incidental. $\$ 2^{\circ}$ A lei local poderá instituir juiz conciliador ou recrutar conciliadores para auxiliarem o juiz da causa na tentativa de solução amigável dos conflitos. $\S 3^{\circ}$ Segundo as peculiaridades do caso, outras formas adequadas de solução do conflito poderão ser sugeridas pelo juiz, inclusive a arbitragem, na forma da lei, a mediação e a avaliação neutra de terceiro. $\S 4^{\circ}$ A avaliação neutra de terceiro, a ser obtida no prazo a ser fixado pelo juiz, é sigilosa, inclusive para este, e não vinculante para as partes, sendo sua finalidade exclusiva a de orientá-las na tentativa de composição amigável do conflito. $\S 5^{\circ}$ Obtido o acordo, será reduzido a termo e homologado pelo juiz. $\$ 6^{\circ} \mathrm{Se}$, por qualquer motivo, a conciliação não produzir resultados e não for adotado outro meio de solução do conflito, o juiz, na mesma audiência, fixará os pontos controvertidos, decidirá as questões processuais pendentes e determinará as provas a serem produzidas, designando audiência de instrução e julgamento, se necessário.” (NR)
}

Revista Quaestio Iuris, vol.04, nº1. ISSN 1516-0351 p.245-277 266 


\section{Quaestio Iuris}

de uma parte em dominar a outra, desigualdade em habilidade (ou disposição) para lidar com o assunto podem se mostrar relevantes.

Achamos válido focar em quatro critérios para avaliar o que será necessário para se obter um processo de mediação bem sucedido:

1) Cada uma das partes está motivada a mediar (e estão essas motivações consistentes com os objetivos da mediação)?

2) Estão prontas a serem responsáveis por tomar as decisões que precisam ser tomadas?

3) Estão dispostas a lidar diretamente uma com a outra (incluindo o conflito)?

4) Estão abertas a alcançar um resultado que seja aceitável para ambas?

A decisão de mediar ou não deve ser informada, além de ser suscetível à reconsideração. A hesitação da parte deve ser encarada com seriedade; cada parte deve estar disposta a mediar (atitude voltada para o entendimento) para que o processo seja significativo. O mediador tem a responsabilidade de observar esta questão e ajudar a esclarecer seus diferentes elementos.

Entender e deixar explícitas as motivações para mediar pode ser um enorme auxílio para alcançar um resultado.

Por fim, a decisão de ir adiante com a mediação deve ter a concordância de todos os envolvidos. A decisão de mediar ou de continuar a mediar não deve ser afetada por um julgamento. Se as partes não estiverem prontas a trabalhar no contexto da mediação, os fatores indicativos dela devem mudar para que em algum momento adiante a mediação possa ser novamente tentada.

Por outro lado, uma decisão inicial de seguir com a mediação é sempre matéria a ser revisada conforme as partes se confrontem com a realidade de suas diferenças e as decisões que precisam ser tomadas.

A decisão de não mediar ou de interromper a mediação não significa que só reste as pessoas a opção de uma demanda adversarial. É preciso trabalhar todas as possibilidades.

Diante de todas as considerações expostas ao longo do trabalho, fruto de demoradas análises do tema sob os mais diversos ângulos, pensamos que algumas conclusões podem ser expostas, na tentativa de ofertar algum material crítico para os operadores do direito, a partir da introdução no direito brasileiro de uma disciplina positivada para a mediação. 
Nessa perspectiva é nosso sentir que o aperfeiçoamento do aparelho judiciário e da administração da justiça não correspondeu ao progresso científico do direito processual ${ }^{52}$. Ademais, ainda estamos longe de atingir, no Brasil, a existência plena de um perfil dos magistrados que se alinhem à postura do Juiz Hermes.

De outro lado, a mediação não deve ser utilizada na generalidade dos casos. Tal conduta equivocada levaria a uma falsa esperança em mais uma forma de solução de conflitos que não tem o condão de se desincumbir, satisfatoriamente, de certos tipos de litígios. $\mathrm{O}$ mediador não tem bola de cristal e nem "varinha mágica".

Como já tivemos oportunidade de ressaltar ${ }^{65}$, a mediação deve ser utilizada, preferencialmente, em disputas envolvendo pessoas físicas que não só mantém entre si um vínculo duradouro que resistirá aquele processo, como também serão influenciadas por ele no futuro.

Deve ser instituído um mecanismo prévio e obrigatório para a tentativa da solução negociada dos conflitos, ainda que não necessariamente a mediação.

O autor, ao ajuizar a petição inicial, deveria alegar (e provar) ao magistrado que tentou, de alguma forma, solucionar pacificamente aquele conflito e que só está levando aquela causa ao Poder Judiciário porque não obteve sucesso em suas tentativas.

O juiz, se se convencer das alegações do autor, profere o despacho liminar positivo e determina a citação do réu; se entender, ao contrário, que há espaço e viabilidade para uma solução pacífica, designa uma sessão de mediação (incidental).

A mediação deve ser conduzida por profissionais habilitados, treinados e experimentados. Cada mediação envolve um conhecimento mais aprofundado do caso, técnicas específicas para o enfrentamento dos mais diversos tipos de conflitos, o estabelecimento de uma relação de confiança e uma postura ética inquestionável do mediador.

Como já foi referido, inúmeras vezes, ao longo to texto, é imperiosa a mudança de mentalidade entre os operadores do direito; há que se abandonar a cultura da sentença e adotar a cultura da pacificação e do entendimento mútuo.

Tal mudança de mentalidade, contudo, deve ser iniciada nos bancos das faculdades de direito. Disciplinas como "teoria do conflito", "mecanismos de solução alternativa de conflitos",

\footnotetext{
52 "A sobrecarga dos tribunais, a morosidade dos processos, seu custo, a burocratização da justiça, certa complicação procedimental; a mentalidade do juiz, que deixa de fazer uso dos poderes que os códigos lhe atribuem; a falta de informação e de orientação para os detentores dos interesses em conflito; as deficiências do patrocínio gratuito, tudo leva a insuperável obstrução das vias de acesso à justiça e ao distanciamento cada vez maior entre o Judiciário e seus usuários. O que não acarreta apenas o descrédito na magistratura e nos demais operadores do
} 


\section{Quaestio Iuris}

vol.04, n0.01. ISSN 1516-0351

"negociação" e "conciliação" devem ser introduzidas nos programas de graduação.

direito, mas tem como preocupante consequiência a de incentivar a litigiosidade latente, que freqüentemente explode em conflitos sociais, ou de buscar vias alternativas violentas ou de qualquer modo inadequadas (desde a justiça de mão própria, passando por intermediações arbitrárias e de prepotência, para chegar até os 'justiceiros')". GRINOVER, Ada Pellegrini. DINAMARCO, Cândido Rangel. WATANABE, Kazuo. Participação e Processo. São Paulo: Revista dos Tribunais, 1988, p. 278.

${ }^{65}$ PINHO, Humberto Dalla Bernardina de Pinho. Mediação: a redescoberta de um velho aliado na solução de conflitos. In Acesso à Justiça: efetividade do processo, [org. Geraldo Prado]. Rio de Janeiro: Lumen Juris, 2005, p. 105-124.

Toda Faculdade de Direito deveria ter, ao menos, uma dessas matérias em sua grade de disciplinas obrigatórias. Ademais, os escritórios modelos deveriam incluir um período de "clínica de mediação", tendo o suporte de uma equipe interdisciplinar, formada por psicólogos, assistentes sociais e terapeutas, de forma a permitir uma formação mais adequada ao acadêmico. Apenas com a mudança na Academia será possível observar a mudança na mentalidade dos operadores.

Aliado a isso, é preciso uma grande e prolongada campanha de esclarecimento à população a fim de que, de um lado, não se criem falsas expectativas; e, de outro, não se permita uma desconfiança quanto ao novo instituto, fruto de uma tradição ligada ao fato de que apenas o juiz "Hércules" pode resolver o problema.

O sistema de mediação prévia e incidental deve ser repensado, sob pena de submeter o processo a mais uma desnecessária delonga. É preciso uma racionalização na prestação jurisdicional.

Se, desde o início, fica claro que o cerne da controvérsia não é jurídico, ou seja, não está relacionado à aplicação de uma regra jurídica, de nada adianta iniciar a relação processual, para então sobrestá-la em busca de uma solução consensual. Isto leva ao desnecessário movimento da máquina judicial, custa dinheiro aos cofres públicos, sobrecarrega juízes, promotores e defensores e, não traz qualquer conseqüência benéfica.

É preciso amadurecer, diante da realidade brasileira, formas eficazes de fazer essa filtragem de modo a obter uma solução que se mostre equilibrada entre os Princípios do Acesso à Justiça e da Duração Razoável do Processo.

Ainda nessa linha de raciocínio, parece ser um verdadeiro despautério cogitar da existência, num mesmo processo, de uma sessão de mediação, uma audiência preliminar e ainda uma AIJ na qual, novamente, tenta-se a conciliação.

Pensamos que, em regra, a conciliação deve ser pré-processual, facultando-se as partes a possibilidade de provocar o Poder Judiciário para obter a homologação do acordo (e com isso mais segurança jurídica para aquela relação); iniciado o fluxo processual, a opção da conciliação 


\section{Quaestio Iuris}

fica sempre aberta, mas não cabe mais ao Juiz buscá-la, provocá-la ou mesmo interromper a marcha dos atos processuais no afã obsessivo de alcançá-la. Tal iniciativa deve competir às partes e não ao magistrado.

A questão de ser o mediador um advogado ou não, tem suscitado grandes discussões. Infelizmente, o que move os debatedores não é uma preocupação desinteressada pelo tema. Há um forte "lobby" de setores da advocacia, em oposição ao movimento feito por setores e grupos ligados à psicologia.

Realmente, não nos parece adequado que o mediador seja, necessariamente, um advogado, em nenhuma hipótese. Pensamos que a melhor configuração é a de um mediador não advogado, que pode ser auxiliado por um co-mediador advogado.

Participando da sessão de mediação estarão as partes que poderão levar seus advogados ou solicitar a intervenção de um defensor público ou advogado dativo, naquelas localidades nas quais a Defensoria Pública ainda não estiver estabelecida, ou quando o número de defensores disponíveis não for suficiente para atender a todas as demandas.

Diga-se, de passagem, que o árbitro, que tem poder de julgar, não precisa ser advogado. Por que, então, o mediador deveria ser, já que sua função não é julgar, mas sim auxiliar as partes e entender melhor o problema, aparando as arestas e removendo os obstáculos que impedem o acordo? O que é verdadeiramente importante é que o mediador seja alguém que tenha autoridade moral na comunidade e que sua habilidade para pacificar os conflitos seja reconhecida de forma geral.

Costumamos dizer que ninguém deve se apresentar como mediador; essa qualidade é atribuída pela sociedade a partir da observação e do reconhecimento das atitudes daquela pessoa. Hoje, os árbitros mais bem sucedidos e requisitados no mercado são pessoas que devotaram suas vidas à construção de uma reputação sólida e confiável.

É a opção do legislador privilegiar a mediação “passiva”, que não é de nossa tradição.

Desde o ano de 1995, com o advento da Lei dos Juizados Especiais, e a conseqüente "popularização" da justiça de pequenas causas, a população se acostumou com a figura do conciliador nos Juizados Especiais que pratica, na maioria dos casos, a mediação "ativa”, ou seja, interfere no conflito, oferece soluções, sugestões e mesmo valores.

Ao se optar pela mediação passiva, quer se queira ou não, faz-se a escolha por um procedimento mais demorado, profundo e que depende da habilidade do mediador em trazer as partes para um

Revista Quaestio Iuris, vol.04, nº1. ISSN 1516-0351 p.245-277 270 


\section{Quaestio Iuris}

vol.04, n0.01. ISSN 1516-0351

conhecimento mais próximo do problema, fazendo com que enxerguem determinados aspectos, sem, contudo, sugestioná-las ou de alguma forma interferir na sua cognição.

Se não houver um treinamento adequado (que demanda estrutura, tempo e muitas horas de clínica e exercícios) a opção do legislador não passará de uma norma programática e absolutamente divorciada da realidade prática.

O legislador não menciona a figura do "caucus", ou seja, a possibilidade do mediador, durante o processo de mediação, reunir-se em separado com apenas uma das partes.

Trata-se de técnica controvertida, mas aceita majoritariamente pela doutrina clássica norteamericana, e que tem por objetivo assegurar que as partes estejam sempre no mesmo nível de compreensão do problema.

Por outro lado, os críticos dessa postura, como os adeptos da Escola de Harvard ${ }^{53}$, lembram que isso traz insegurança e desconfiança para a parte que não participou da sessão privada, podendo frustrar todo o processo, posição essa que, apesar de tornar mais longo e complexo o caminho da solução do conflito, parece, sem dúvida, ser a mais isonômica e transparente.

A efetivação do cadastro e do registro de mediadores é de suma importância, bem como a postura da $\mathrm{OAB}$ que, ao contrário das tradições corporativistas, deve dar o exemplo e punir todo e qualquer profissional que contribua, de alguma forma, para o desvirtuamento do processo de mediação.

Não é necessário referir aqui, posto que notórios, os incontáveis casos de falsidade, desvio e abuso de direitos, poderes e prerrogativas por pessoas que, a pretexto de exercerem a função de árbitros, procuravam-se travestir em falsos juízes de direito.

A redação do artigo 34, ao dispor sobre os casos em que não é cabível a mediação parece equivocada.

A proibição de seu uso no inventário chega a ser absurda, em razão da desjudicialização desse procedimento, promovida pela Lei $\mathrm{n}^{\circ} 11.441 / 07$.

Quer nos parecer que a Lei deve, apenas, fixar as premissas básicas, sem arrolar casos específicos.

Em outras palavras, o critério para a determinação dos casos nos quais pode ser feita a mediação deve ser ope iudicis e não ope legis. Havendo dúvida, devem as partes procurar o Poder

\footnotetext{
${ }^{53}$ HARVARD LAW SCHOOL. Advanced Mediation Workshop. Program of Instruction for Lawyers. Textbook and class materials. Cambridge, Massachusetts, June, 2004. Sob a perspectiva dos negociadores, veja-se: MNOOKIN, Robert H. Beyond Winning, Cambridge: Harvard University Press, 2000; e BRESLIN, J. William \& RUBIN, Jeffrey Z. Negotiation Theory and Practice, Cambridge: Harvard University Press, 1999.
} 
Judiciário e distribuir uma petição, ainda que com a finalidade de obter apenas a homologação judicial.

O Direito, toda vez que é aplicado como mecanismo de resolução de disputas, deixa marcas na sociedade e talvez aí esteja sua grande vantagem, a estipulação de comportamento futuro como parte de sua função educativa e protetora.

Entretanto, quando é instrumento de determinação de perda ou ganho em um conflito, concorre sempre para a multiplicação ou potencialização do conflito.

Como é preciso encerrar em algum momento e as matérias suscitadas nesse texto abrem caminho para tantos outros questionamentos, gostaríamos de dizer, por último, que a mediação é um extraordinário instrumento que possibilita a compreensão do conflito a partir da participação efetiva dos envolvidos, sendo, pois, mecanismo que se alinha perfeitamente ao modelo democrático-pluralista do juiz Hermes, ao postulado da máxima cooperação ${ }^{54} \mathrm{e}$, ainda, à moldura da teoria do discurso e de uma racionalidade comunicativa.

Parece-nos que ao longo da (recente) tradição democrática brasileira, talvez até mesmo como uma expressão da mea culpa do Estado, ciente de seu fracasso ao atender as necessidades mais básicas da população, forjou-se a idéia de que o Poder Judiciário deve ter uma posição paternalista em relação ao jurisdicionado.

O cidadão procura o Juiz "Hércules", “despeja” seu problema e fica ao lado, aguardando impacientemente, reclamando e espraguejando se a solução demora ou se não vem do jeito que

\footnotetext{
${ }^{54}$ Tratando dos modelos normativos de democracia, após preconizar a insuficiência dos modelos liberal e social, Hermes Zaneti Júnior aponta para a máxima cooperação processual como única forma capaz de dar conta das complexidades do Estado Democrático de Direito. Vejam-se as suas palavras: "A proposta que se entende deva prevalecer é a que reconhece a "máxima cooperação", como observância da participação das partes e como alternativa aos discursos antagônicos, uma composição fundada na tentativa de harmonizar, pelo discurso e pela "pretensão de correção", a contraposição entre os objetivos sociais e as liberdades individuais do processo". (ZANETI JÚNIOR, Hermes. Processo Constitucional: O Modelo Constitucional do Processo Civil Brasileiro. Rio de Janeiro: Lumen Júris, 2007. Obj. de citação pp. 165-166.) Sobre o Princípio da Máxima Cooperação no Processo conferir, também: OLIVEIRA, Carlos Alberto Alvaro de. Poderes do Juiz e visão cooperativa do processo. In: AJURIS: Revista da Associação dos Juízes do Rio Grande do Sul. Porto Alegre, ano XXX, nº. 90, pp. 55-84, jun. 2003.

55 "A sociedade aprendeu a levar os conflitos para os tribunais. Com as leis aprendeu a evitar a violência, a guerra e a cobrança de seus interesses, necessidades e direitos, com as próprias mãos. Mas esqueceu como resolver conflitos em meio a essas mesmas necessidades e interesses delegando poderes que só ela por si pode exercer. Esqueceu como conquistar e administrar a paz”. SERPA, Maria de Nazareth. Teoria e Prática da Mediação de Conflitos, Rio de Janeiro: Lumen Juris, 1999, p. 62.

55 PINHO, Humberto Dalla Bernardina de. Mediação - a redescoberta de um velho aliado na solução de conflitos. In: Acesso à Justiça: efetividade do processo (org. Geraldo Prado). Rio de Janeiro: Lumen Juris, 2005.

56 O termo facilitação vem sendo largamente utilizado na literatura especializada em mediação. Confira-se, por todos, SINGER, Linda R. Settling Disputes. $2^{\text {nd }}$ edition. Colorado: Westview, 1994. Obj. de ref. p. 24.
} 


\section{Quaestio Iuris}

ele deseja. Estamos em que as partes devem ser envolvidas de forma mais direta na solução dos conflitos e a mediação contribuirá, em muito, para isso.

A implementação dessas idéias permitirá que o procedimento da mediação seja gravado com as mesmas garantias inerentes ao processo judicial num Estado Democrático de Direito, viabilizando e justificando esse meio alternativo dentro da exigência de um processo "justo", na ótica da moderna doutrina processual italiana ${ }^{56}$ e obediente aos postulados clássicos do due process of law.

\section{BIBLIOGRAFIA}

1. ÁLVAREZ. Gladys Stella. La Mediación y el Aceso a Justicia. Buenos Aires: RubinzalCulzoni Editores, 2003.

2. ANDRIGHI, Fátima Nancy. Juiz contemporâneo deve ser um pacificador. Notícia veiculada no endereço eletrônico www.stj.gov.br, em 25/08/2006.

3. ASCENSÃO, José de Oliveira. Introdução à ciência do Direito. $3^{\mathrm{a}}$ ed. Rio de Janeiro: Renovar, 2005.

4. AZEVEDO, André Gomma. Perspectivas metodológicas do processo de mediação: apontamentos sobre a autocomposição no direito processual, In Estudos em Arbitragem, Mediação e Negociação, vol. 2. Brasília: Grupos de Pesquisa UnB, 2003. Disponível no sítio http://www.unb.br/fd/gt/Volume2.pdf, consultado em 06.12.2006.

5. BACELLAR, Roberto Portugal. Juizados especiais - a nova mediação paraproccssual. São Paulo: Revista dos Tribunais.

6. BARBOSA MOREIRA, José Carlos. Breve noticia sobre la conciliación em el proceso civil brasileño, In Temas de Direito Processual, $5^{a}$ série. Rio de Janeiro: Saraiva, 1994.

7. CAIVANO, Roque J.; GOBBI, Marcelo; PADILLA, Roberto E. Negociación y Mediación: Instrumentos apropiados para la abogacía moderna. 2. ${ }^{a}$ edición actualizada y ampliada. Buenos Aires: Ad-Hoc, 2006.

8. CALMON, Petrônio. Fundamentos da Mediação e da Conciliação, Rio de Janeiro: Forense, 2007.

\footnotetext{
${ }^{56}$ Ver, por todos, COMOGLIO, Luigi Paolo. Garanzie Costituzionali e "Giusto Processo" (Modelli a confronto) in Revista de Processo, vol. 90, ano 23, abr-jun/1998, São Paulo: Revista dos Tribunais, p. 95-148;

Garanzie Minime del "Giusto Processo" Civile negli ordinamenti ispano-latinoamericani in Revista de Processo, vol. 112, ano 28, out/dez/2003, São Paulo: Revista dos Tribunais, p. 159-176; TARZIA, Giuseppe. L’Art 111 Cost. e le
} 
9. CAPPELLETTI, Mauro [s/ indicação de tradutor], Os Métodos Alternativos de Solução de Conflitos no Quadro do Movimento Universal de Acesso à Justiça, In Revista de Processo, vol. 74. São Paulo: Revista dos Tribunais, 1994.

10. CAPPELLETTI, Mauro; GARTH, Bryant. Acesso à Justiça. Trad. Ellen Gracie Northfleet. Porto Alegre: Sergio Antonio Fabris Editor, 1988, reimpresso 2002.

11. DIDIER JÚNIOR, Fredie. Curso de Direito Processual Civil: Teoria Geral do Processo e Processo de Conhecimento. Vol. 1. 9a ed. rev. ampl. atu. Salvador: Juspodivm, 2008.

12. FISCHER, Roger and William Ury. Getting to Yes: Negotiating Agreement without Giving In. Boston: Houghton Mifflin Co., 1981.

Garanzie Europee des Processo Civile in Revista de Processo, vol. 103, ano 26, jul-set/2001, São Paulo: Revista dos Tribunais, p. 156-174. 
13. FISS, Owen. Um novo processo civil. Trad. Carlos Alberto de Salles. São Paulo: Ed. RT, 2004.

14. FULLER, Lon L. The Forms and Limits of Adjudication, In Harvard Law Review 353. 1978.

15. GOLDBERG, Stephen B., SANDER, Frank E.A., ROGERS, Nancy H., COLE, Sarah R. Dispute Resolution - Negotiation, Mediation, and Other Processes, $4^{\text {th }}$ edition. New York: Aspen Publishers, Inc, 2003.

16. GRECO, Leonardo. Garantias Fundamentais do Processo: O Processo Justo. Disponível na Internet: 〈http://www.mundojuridico.adv.br>. Acesso em 20/12/2006.

17. GRINOVER, Ada Pellegrini. A Conciliação extrajudicial no quadro participativo, in Novas Tendências do Direito Processual. São Paulo: Revista dos Tribunais, 1988.

18. HABERMAS, Jürgen. Direito e Democracia: entre facticidade e validade. Vol. I. Tradução: Flávio Beno Siebeneichler. Rio de Janeiro: Tempo Brasileiro, 1997.

19. HARVARD LAW SCHOOL. Advanced Mediation Workshop. Program of Instruction for Lawyers. Textbook and class materials. Cambridge, Massachusetts, June, 2004.

20. LUCHI, José Pedro. A racionalidade das decisões jurídicas segundo Habermas. In: Ajuris: Revista da Associação dos Juízes do Rio Grande do Sul. Porto Alegre, ano XXXIV, nº 107, pp. 157-170, setembro de 2007.

21. A lógica dos Direitos Fundamentais e dos Princípios do Estado. In: Linguagem e Sociabilidade. José Pedro Luchi (org.) Vitória: EDUFES, 2005.

22. MARINONI, Luiz Guilherme. A Jurisdição no Estado Contemporâneo. In: (Coord.). Estudos de Direito Processual Civil: homenagem ao Professor Egas Dirceu Moniz de Aragão. São Paulo: Revista dos Tribunais, 2005, pp. 13-66.

23. Do processo civil clássico à noção de direito a tutela adequada ao direito material e à realidade social. Disponível na Internet: <http://www.mundojuridico.adv.br>. Acesso em 08 de novembro de 2006.

24. Curso de Processo Civil: Teoria Geral do Processo. Vol. 1. São Paulo: Revista dos Tribunais, 2006.

25. MARTÍN, Nuria Belosso. Reflexiones sobre Mediación Familiar: Algunas Experiencias en el Derecho Comparado. In Revista de Direito Privado no 24, out./dez. 2005 (coord. Nelson Nery Jr. e Rosa Maria de Andrade Nery). São Paulo: Revista dos Tribunais, 2005. 
26. L L L L regeneración de la democracia y del demos a través de la deliberación: democracia liberal, democracia republicana y democracia neoconstitucional. Artigo cedido pela autora em 02.05.08, a ser publicado na Revista Jurispoiesis da UNESA.

27. MONTESQUIEU. Do espírito das leis. São Paulo: Abril Cultural, 1973.

28. MOORE, Christopher W. The Mediation Process - Practical Strategies for Resolving Conflict. 3rd Edition. San Francisco: Jossey-Bass, 2003.

29. MNOOKIN, Robert H. Why negotiations fail: an exploration of barriers to the resolution of conflict, The Ohio State Journal on dispute resolution. vol. 8, nº 2, 1993.

30. OLIVEIRA, Carlos Alberto Alvaro. O formalismo-valorativo no confronto com o formalismo excessivo. In: DIDIER JR., Fredie (Org.). Leituras Complementares de Processo Civil. $5^{\text {a }}$ ed. rev. atu. Salvador: Juspodivm, 2007, pp. 351-372.

31. Do formalismo no processo civil. $2^{\mathrm{a}}$ ed. rev. São Paulo Saraiva, 2003.

32. Poderes do Juiz e visão cooperativa do processo. In: AJURIS: Revista da Associação dos Juízes do Rio Grande do Sul. Porto Alegre, ano XXX, nº. 90, pp. 55-84, jun. 2003.

33. OST, François. Júpter, Hércules, Hermes: Tres modelos de Juez. In: DOXA, nº 14, 1993. pp. 169-194. <http://www.cervantesvirtual.com/servlet/SirveObras/

01360629872570728587891/index.htm>. Acesso em 14 de novembro de 2006.

34. PINHO, Humberto Dalla Bernardina de. Mecanismos de Solução Alternativa de Conflitos: algumas considerações introdutórias, In Revista Dialética de Direito Processual, vol 17. São Paulo: Oliveira Rocha, 2004.

35. Mediação - a redescoberta de um velho aliado na solução de conflitos, in Acesso à Justiça: efetividade do processo (org. Geraldo Prado). Rio de Janeiro: Lumen Juris, 2005.

36. [organizador]. Teoria Geral da Mediação à luz do Projeto de Lei e do Direito Comparado. Rio de Janeiro: Lumen Juris, 2008.

37. RESTA, Eligio (trad. Sandra Vial). O Direito Fraterno. Santa Cruz do Sul, EDUNISC, 2004.

38. SALES, Lília Maia de Morais. Justiça e Mediação de Conflitos. Belo Horizonte: Del Rey, 2004.

39. SERPA, Maria de Nazareth Serpa. Teoria e Prática da Mediação de Conflitos. Rio de Janeiro: Lumen Juris, 1999. 
40. SILVA, João Roberto da. A Mediação e o Processo de Mediação. São Paulo: Paulistanajur, 2004.

41. TARELLO, Giovanni. Storia della cultura giuridica moderna. Bologna: Il Mulino, 1976.

42. VAZ, Alexandre Mário Pessoa. Poderes e Deveres do Juiz na Conciliação Judicial. Vol. I, Tomo I. Coimbra: Coimbra Editora, 1976.

43. WATANABE, Kazuo. Cultura da Sentença e Cultura da Pacificação, in Estudos em Homenagem à Professora Ada Pellegrini Grinover (org. Flávio Luiz Yarchell e Maurício Zanoide de Moraes). São Paulo: DPJ, 2005.

44. ZANETI JÚNIOR, Hermes. Processo Constitucional: O Modelo Constitucional do Processo Civil Brasileiro. Rio de Janeiro: Lumen Júris, 2007. 